\title{
GAMBARAN KARAKTERISTIK DAN STATUS IMUNISASI PENDERITA DIFTERI DI PROVINSI JAWA TIMUR TAHUN 2018
}

\author{
An Overview of Characteristics and Immunization Status of \\ Diphteria Sufferers in East Java Province at 2018
}

\author{
Dwi Rismayanti Wigrhadita \\ Departemen Epidemiologi, Fakultas Kesehatan Masyarakat Universitas Airlangga Surabaya, \\ email: Dwi.Rismayanti.Wigrhadita-2015@fkm.unair.ac.id
}

\begin{abstract}
In 2016 East Java was the region with the highest cases of diphtheria, namely 209 cases with 6 deaths. In 2017 diphtheria cases in East Java increased to 460 cases with 16 deaths, and continued to increase in 2018, namely 758 cases with a death rate of 3 people. This research aims to describe the characteristics and immunization status of diphtheria sufferers in East Java Province in 2018. This research is a descriptive research type with a cross sectional study design. The research population were all people who were declared diphtheria in East Java Province in 2018. The method of sampling is to use the total population. The variables were the characteristics and immunization status of diphtheria sufferers. Data were analyzed using univariate analysis with frequency table. The result shows that characteristics of diphteria sufferers were dominated by age $\geq 19$ years (33.11\%) and male sex (50.6\%). Diphtheria sufferers are dominated by incomplete immunization status (98.15\%). The conclusion shows that completeness of 7-dose diphtheria immunization plays an important role in the occurrence of diphtheria cases in East Java Province in 2018, especially patients who have not carried out immunizations at all.
\end{abstract}

Keywords: $\quad$ Diphtheria cases, characteristics, immunization status, diphtheria sufferers, East Java Province

\begin{abstract}
Abstrak
Di tahun 2016 Jawa Timur menjadi wilayah dengan kasus difteri tertinggi yaitu sebanyak 209 kasus dengan 6 kematian. Di tahun 2017 kasus difteri di Jawa Timur bertambah menjadi 460 kasus dengan 16 kematian, serta terus mengalami peningkatan di tahun 2018 yaitu terjadi 758 kasus dengan angka kematian sebanyak 3 orang. Penelitian ini bertujuan untuk menggambarkan karakteristik dan status imunisasi penderita difteri di Provinsi Jawa Timur tahun 2018. Penelitian ini merupakan jenis penelitian deskriptif dengan rancang bangun cross sectional study. Populasi dalam penelitian ini adalah semua orang yang dinyatakan difteri di Provinsi Jawa Timur tahun 2018. Cara pengambilan sampel yaitu dengan menggunakan total populasi. Variabel dalam penelitian ini yaitu karakteristik dan status imunisasi penderita difteri. Analisis data berupa analisis univariate dengan menyajikan tabel frekuensi. Hasil dari penelitian menunjukkan bahwa karakteristik penderita didominasi oleh usia $\geq 19$ tahun $(33,11 \%)$ dan berjenis kelamin laki-laki $(50,6 \%)$. Penderita difteri didominasi dengan status imunisasi yang tidak lengkap $(98,15 \%)$. Kesimpulan dari penelitian ini yaitu kelengkapan imunisasi difteri 7 dosis sangat berperan penting dalam terjadinya kasus difteri di Provinsi Jawa Timur tahun 2018, khususnya penderita yang sama sekali tidak melakukan imunisasi.
\end{abstract}

Kata kunci: kasus difteri, karakteristik, status imunisasi, penderita difteri, Provinsi Jawa Timur

\section{PENDAHULUAN}

Penyakit difteri adalah salah satu penyebab kematian bayi dan balita karena rendahnya kekebalan sistem imun dimana penyakit ini dapat dicegah dengan imunisasi (PD3I) (Munawaroh, 2016). Di beberapa negara penyakit difteri masih dianggap menjadi masalah kesehatan. Penyakit difteri disebabkan adanya infeksi dari bakteri Corynebacterium diptheriae (White and Hien, 2009). Sejak tahun 2000-2015 Indonesia menjadi bagian dari 10 negara yang memilliki kasus difteri tertinggi di dunia. Indonesia menduduki posisi kedua terbanyak insiden difteri dibandingkan dengan negara anggota SEARO (South-East Asia Region) lainnya. Peningkatan tren kasus difteri 
di Indonesia selalu terjadi setiap tahun. Pada tahun 2015 terjadi 415 kasus dan 24 kematian akibat panyakit difteri di Indonesia. CFR (Case Fatality Rate) difteri tahun 2016 sebesar 5,80\%. Dalam beberapa tahun terakhir Provinsi Jawa Timur adalah wilayah dengan insiden difteri tertinggi di Indonesia. Semua kabupaten atau kota di wilayah Jawa Timur pada tahun 2011 dan 2012 telah mengalami KLB difteri (Dinkes Jatim, 2013). Di tahun 2016 Jawa Timur juga menjadi wilayah dengan sebaran kasus difteri tertinggi yaitu sebanyak 209 kasus dengan 6 kematian (Kemenkes RI, 2017). Di tahun 2017 kasus difteri di Jawa Timur bertambah menjadi 460 kasus dengan 16 kematian, serta terus mengalami peningkatan di tahun 2018 yaitu terjadi 758 kasus dengan angka kematian sebanyak 3 orang (Dinkes Kota Surabaya, 2018). Upaya pencegahan melalui imunisasi dirasa belum maksimal terhadap kasus difteri (Clarke, 2017). Segala macam bentuk upaya telah dilakukan untuk mengatasi KLB difteri di Jawa Timur yaitu pengadaan Outbreak Response Immunization (ORI), Backlog Fighting (BLF), dan sempat mengadakan sub Pekan Imunisasi Nasional (PIN), tetapi kasus difteri terus mengalami peningkatan. Peningkatan yang terus terjadi di wilayah Jawa Timur merupakan kurang maksimalnya upaya penekanan kasus difteri melalui cakupan imunisasi difteri khusushnya imunisasi difteri 7 dosis (Dinkes Kota Surabaya, 2018).

Penyakit difteri dapat dicegah dengan pemberian imunisasi. Imunisasi merupakan intervensi kesehatan yang sangat efektif dalam menurunkan angka kemaian dan kesakitan pada bayi dan balita. Pemberian imunisasi bertujuan untuk membentuk kekebalan kelompok (herd immunity). Kekebalan tersebut akan tercapai apabila suatu daerah memiliki cakupan imunisasi yang tinggi. Cakupan imunisasi di suatu wilayah ditargetkan pemerintah harus melebihi $80 \%$ baik di tingkat nasional, provinsi, kabupaten, bahkan setiap desa (IDAI, 2011). WHO pada tahun 1992 menargetkan cakupan imunisasi booster harus mencapai $95 \%$ pada anak usia sekolah di semua wilayah (Dinkes Jatim, 2011). Imunisasi ulangan (booster) merupakan imunisasi yang diberikan setelah pemberian imunisasi dasar atau pada anak usia Sekolah Dasar (SD) kelas 1 dan apabila sampai dengan usia 5 tahun anak belum pernah mendapatkan imunisasi Hepatitis $\mathrm{B}$, maka secepatnya diberikan imunisasi Hepatitis B dengan jadwal 3 kali pemberian. Hal ini mendukung bahwa di Indonesia, pemberian imunisasi tidak merata dan tidak semua anak mendapatkan imunisasi. Alasan mayoritas anak tidak mendapatkan imunisasi adalah petugas yang tidak hadir (Rahmawati dan Wahyuni, 2014). Alasan lainnya yaitu kurangnya pengetahuan ibu mengenai imunisasi, kepercayaan terhadap pemberian vaksin, kurang tersedianya vaksin, serta biaya yang tidak terjangkau.

Beberapa penelitian menunjukkan bahwa pemberian imunisasi merupakan faktor risiko kejadian difteri. Individu yang tidak diimunisasi (DPT/DT) akan lebih besar berisiko untuk menderita difteri dibandingkan dengan yang diimunisasi (Mukarami et al., 2010). Hal tersebut sejalan dengan hasil penelitian yang menujukkan faktor paling dominan dengan kasus difteri di Puskesmas Bangkalan tahun 2016, yaitu seorang anak yang tidak mendapatkan imunisasi DPT berisiko 5 kali lebih besar untuk terinfeksi difteri dibandingkan dengan anak yang mendapatkan imunisasi DPT (Rahmawati dan Wahyuni, 2014). Penelitian sebelumnya juga menunjukkan bahwa imunisasi DPT3 dan DT merupakan faktor yang berpengaruh terhadap jumlah penderita difteri (Izza dan Soenarnatalina, 2015). Penelitian ini bertujuan untuk menggambarkan karakteristik dan status imunisasi penderita difteri di Provinsi Jawa Timur tahun 2018.

\section{METODE PENELITIAN}

Penelitian ini merupakan jenis penelitian deskriptif dengan rancang bangun cross sectional study. Populasi dalam penelitian ini adalah semua orang yang dinyatakan difteri dari 29 kabupaten dan 9 kota di Provinsi Jawa Timur tahun 2018. Cara pengambilan sampel yaitu dengan menggunakan total populasi. Data penelitian ini berupa data sekunder dari publikasi profil kesehatan Provinsi Jawa Timur tahun 2018 yang didapatkan dari Dinas Kesehatan Provinsi, yaitu lembaga yang menyediakan data jumlah penderita penyakit difteri serta faktor yang diduga berpengaruh terhadap kasus difteri di Jawa Timur tahun 2018. Data yang dikumpulkan dikelompokkan dan dianalisis secara univariate. Analisis univariate disajikan dalam bentuk deskriptif dengan tabel frekuensi. Data tersebut diinterpretasi serta dibandingkan dengan teori, standar, pedoman, mengidentifikasi masalah, 
serta mencari alternatif solusinya. Variabel dalam penelitian ini yaitu karakteristik dan status imunisasi penderita difteri. Pelaksanaan penelitian ini dilakukan pada bulan Januari 2019 di Dinas Kesehatan Provinsi Jawa Timur.

\section{HASIL PENELITIAN}

\section{Karakteristik Penderita Difteri di Provinsi Jawa Timur Tahun 2018}

Berdasarkan hasil data sekunder dari Provinsi Jawa Timur terjadi peningkatan kasus secara terus menerus sejak tahun 2016 hingga tahun 2018. Di tahun 2016 Jawa Timur juga menjadi wilayah dengan sebaran kasus difteri tertinggi yaitu sebanyak 209 kasus dan kematian sebanyak 6 orang. Di tahun 2017 kasus difteri di Jawa Timur bertambah menjadi 460 kasus dengan 16 kematian, serta terus mengalami peningkatan di tahun 2018 yaitu terjadi 758 kasus dengan angka kematian sebanyak 3 orang (Gambar 1). Persebaran kasus difteri berdasarkan segitiga epidemiologi dapat dibedakan menjadi orang, tempat, dan waktu. Persebaran kasus berdasarkan orang dapat digolongkan berdasarkan kelompok usia dan jenis kelamin penderita difteri. Pola persebaran kasus difteri berdasarkan karakteristik tempat dapat digolongkan melalui kabupaten dan kota di wilayah Jawa Timur, serta persebaran berdasarkan waktu dapat digolongkan melalui perhitungan bulan.

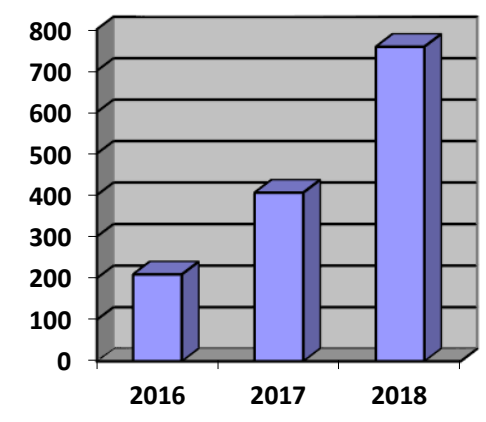

Gambar 1. Kasus Difteri di Provinsi Jawa Timur Tahun 2016-2018

Karakteristik penderita difteri dapat diklasifikasikan melalui kelompok umur dan jenis kelamin (Tabel 1). Hasil penelitian menunjukkan bahwa penderita paling banyak yaitu usia $\geq 19$ tahun $(33,1 \%)$ dan paling sedikit usia $\leq 2$ tahun (7\%). Berdasarkan jenis kelamin penderita difteri paling dominan terjadi pada laki-laki (50,6\%). Pola persebaran kasus difteri dapat digolongkan berdasarkan tempat (Gambar 2) dan berdasarkan waktu (Gambar 3). Berdasarkan tempat persebaran kasus difteri di Jawa Timur tahun 2018 paling tinggi terjadi di Kota Surabaya yaitu sebanyak 75 kasus dan terendah di Kabupaten Bondowoso yaitu terjadi 3 kasus. Pola persebaran kasus difteri yang didasarkan pada waktu yaitu melalui perhitungan bulan (Gambar 4). Hasil penelitian menunjukkan kasus difteri terjadi secara fluktuatif selama tahun 2018. Kasus difteri tertinggi selama tahun 2018 terjadi pada bulan Januari sebanyak 139 kasus dan terendah pada bulan Juni yaitu sebanyak 27 kasus.

Tabel 1. Karakteristik Penderita Difteri Di Provinsi Jawa Timur Tahun 2018

\begin{tabular}{lrr}
\hline \multicolumn{1}{c}{ Variabel } & $\begin{array}{c}\text { Frekuensi } \\
\text { (n) }\end{array}$ & Presentase \\
\hline Usia (tahun) & & \\
\hline 1-2 tahun & 53 & $7 \%$ \\
3-5 tahun & 134 & $17,70 \%$ \\
6-11 tahun & 202 & $26,60 \%$ \\
12-18 tahun & 118 & $15,60 \%$ \\
$\geq 19$ tahun & 251 & $33,10 \%$ \\
\hline Jenis Kelamin & & \\
\hline Laki-Laki & 383 & $50,60 \%$ \\
Perempuan & 374 & $49,40 \%$ \\
Sumber: Dinkesprov, Jawa Timur (2018)
\end{tabular}

\section{Status Imunisasi Penderita Difteri di Jawa Timur Tahun 2018}

Imunisasi merupakan salah satu hal yang mampu mencegah terjadinya kasus difteri. Pemberian imunisasi untuk mencegah penyakit difteri dapat dilakukan secara lengkap dengan memberikan 7 dosis pada masyarakat. Kelengkapan pemberian imunisasi difteri yang diberikan sebanyak 7 kali yaitu terbagi menjadi imunisasi DPT-HB-Hib (Difteri, Pertusis, Tetanus - Hepatitis B - Haemophiluus Influenza tipe B) 1, DPT-HB-Hib 2, DPT-HBHib 3, DPT-HB-Hib booster, DT yang diberikan kelas $1 \mathrm{SD}$, Td (Tetanus Difteri) kelas 2 SD, serta Td yang diberikan kelas 5 SD. Pada penderita difteri gambaran status imunisasi 7 dosis dapat digolongkan berdasarkan usia (Tabel 2). 


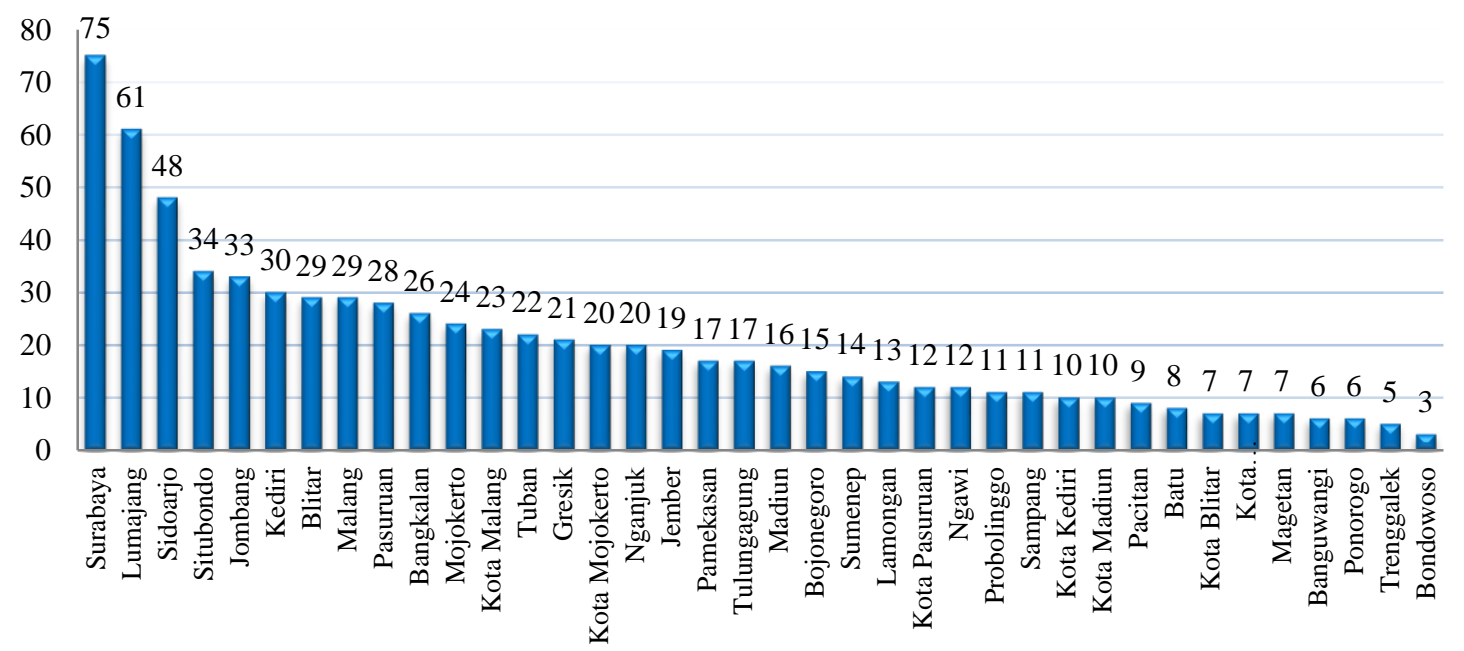

Sumber: Dinkesprov, Jawa Timur (2018)

Gambar 2. Distribusi Kasus Difteri Berdasarkan Tempat Di Provinsi Jawa Timur Tahun 2018

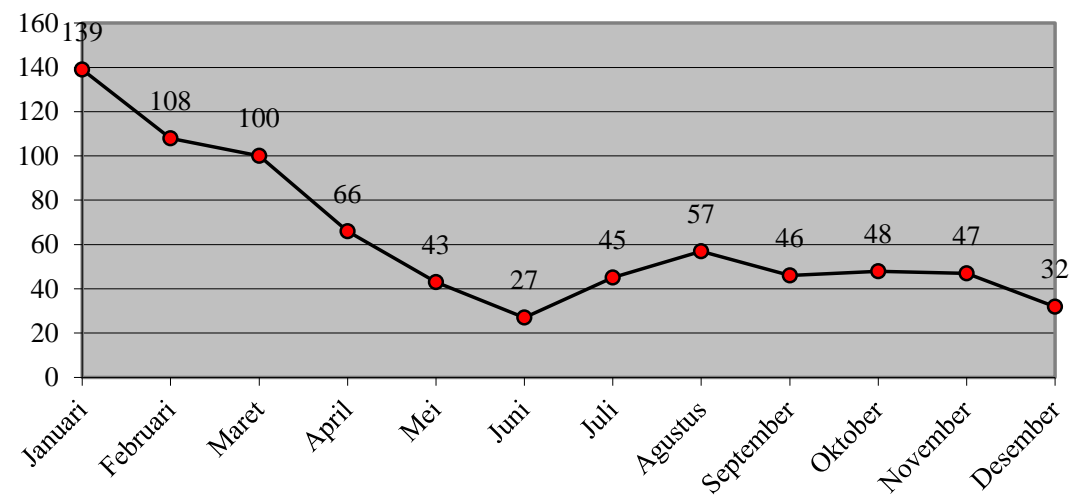

Sumber: Dinkesprov, Jawa Timur (2018)

Gambar 3. Distribusi Kasus Difteri Berdasarkan Waktu Di Provinsi Jawa Timur Tahun 2018

Pada usia 1-2 tahun mayoritas penderita difteri tidak melakukan imunisasi secara lengkap. Rata-rata penderita usia 1-2 tahun hanya melakukan imunisasi sampai dosis ketiga yaitu DPT-HB-Hib 3. Pemberian imunisasi hanya sampai dosis ketiga juga didominasi pada usia 3-5 tahun. Dari 134 penderita difteri usia 35 tahun, sebanyak 41 penderita $(30,59 \%)$ melengkapi imunisasi sampai dosis ketiga. Sebanyak 29 penderita $(21,64 \%)$ tidak melakukan imunisasi sama sekali dan hanya 1 penderita yang melakukan imunisasi secara lengkap.

Di usia 6-11 tahun, mayoritas penderita difteri $(25,74 \%)$ melakukan imunisasi sampai dosis keempat yaitu imunisasi DPT-HB-Hib booster. Pemberian imunisasi lengkap dari segi usia juga didominasi pada usia 6-11 tahun yaitu sebanyak 2,47\%. Berbeda dengan usia 12-18 tahun, penderita difteri didominasi dengan tidak melakukan imunisasi sama sekali $(35,59 \%)$ dan hanya $3,38 \%$ penderita melakukan imunisasi difteri secara lengkap. Di usia $\geq 19$ tahun penderita difteri paling banyak tidak imunisasi $(70,51 \%)$ dan yang melakukan imunisasi lengkap hanya 4 dari 251 penderita $(1,59 \%)$.

\section{HASIL PENELITIAN}

\section{Karakteristik Penderita Difteri di Provinsi Jawa Timur}

Salah satu penyakit yang dapat menyebabkan terjadi Kejadian Luar Biasa (KLB) yaitu penyakit difteri, dimana munculnya satu kasus difteri sudah dapat dikategorikan sebagai KLB (Alfiansyah, 2017). Hasil penelitian ini menunjukkan bahwa kejadian difteri terus mengalami peningkatan. Peningkatan kejadian difteri sejak tahun 2016 hingga tahun 2018 terjadi karena kurang optimalnya dan meratanya pemberian imunisasi. Angka kematian akibat kejadian 
difteri terjadi secara fluktuatif selama tahun 2016-2018, dimana tahun 2016 terjadi 6 kematian, kemudian meningkat tinggi menjadi 16 kematian dan menurun di tahun 2018 menjadi 3 kasus kematian. Penurunan angka kesakitan dan kematian akibat penyakit difteri tersebut karena pemerintah telah melakukan berbagai upaya. Salah satu upaya pemerintah yaitu mengadakan Outbreak Response Immunization (ORI), Backlog Fighting (BLF), serta dilengkapi dengan kegiatan Pekan Imunisasi Nasional (PIN) di beberapa kabupaten dan kota di Jawa Timur (Dinkesprov Jawa Timur, 2016). Penderita kasus difteri didominasi oleh penduduk berusia $\geq 19$ tahun $(33,1 \%)$ dan berjenis kelamin laki-laki $(50,6 \%)$. Mayoritas penderita tersebut seharusnya telah mendapatkan imunisasi difteri secara lengkap (7 dosis), namun kenyataannya pada usia tersebut penderita didominasi tidak melakukan imunisasi $(70,51 \%)$ dan tidak melakukan imunisasi booster $(7,96 \%)$. Hal ini sejalan dengan penelitian Kunarti (2004) dimana semakin bertambahnya umur anak, maka titer bodi akan semakin menurun. Penelitian lain juga menunjukkan bahwa pertambahan usia juga turut meningkatkan risiko terserang difteri bila tidak dilakukan imunisasi ulang (booster) (Aswad dan Shubair, 2009). Seiring bertambahnya usia maka seseorang akan lebih sering berinteraksi dengan banyak orang. Hal tersebut menyebabkan adanya peluang untuk terpapar bakteri Corynebacterium diptheriae yang berasal dari luar wilayah lebih besar dan menjadikan terserang penyakit difteri akan lebih besar juga.

Penderita difteri di Provinsi Jawa Timur tahun 2018 didominasi berjenis kelamin lakilaki. Penderita berjenis kelamin laki-laki dianggap lebih sering melakukan aktivitas diluar rumah dibandingkan dengan yang berjenis kelamin perempuan. Banyaknya aktivitas diluar rumah berisiko terjadi kontak dengan carier difteri khususnya jika banyak aktivitas di daerah yang endemis difteri. Hasil ini berlawanan dengan penelitian lainnya yang menunjukkan bahwa perempuan lebih banyak terinfeksi difteri dibanding laki-laki (Swart et al., 2016). Perempuan memiliki angka Geometric Mean igG Concentrations (GMC) atau titer antibodi difteri yang lebih rendah daripada laki-laki, hal ini menjadikan perempuan lebih rentan terinfeksi difteri. Hasil penerlitian ini berbeda dengan penelitian sebelumnya yang menunjukkan bahwa jenis kelamin tidak berhubungan dengan kejadian difteri di Kota Surabaya, dimana perbedaan daya imunitas dengan jenis kelamin tidak saling berhubungan untuk terkena penyakit difteri (Sari, 2012).

Kasus difteri paling tinggi di wilayah Provinsi Jawa Timur adalah Kota Surabaya. Tingginya kasus difteri di suatu wilayah disebabkan oleh cakupan imunisasi difteri 7 dosis yang rendah. Rendahnya cakupan imunisasi difteri akan menyebabkan penularan penyakit difteri tidak terputus sesuai dengan tujuan pemberian imunisasi. Penyakit difteri dapat dengan mudah dan tersebar secara cepat melalui percikan ludah penderita atau makanan. Risiko penularan difteri pada seseorang yang tidak memperoleh imunisasi jauh lebih besar daripada seseorang yang mendapatkan imunisasi secara lengkap (Hidayati, 2017). Rendahnya cakupan imunisasi di suatu wilayah yang mengakibatkan terjadinya peningkatan kasus difteri membutuhkan adanya sistem surveilans epidemiologi yang bertujuan untuk monitoring dan mengevaluasi keberhasilan imunisasi. Output surveilans tersebut dapat digunakan sebagai landasan pengambilan keputusan terhadap tindakan pencegahan dan penanggulangan kasus difteri. Mobilitas penduduk yang tinggi juga berisiko meningkatkan kemungkinan membawa bibit penyakit dari satu daerah ke daerah lainnya (Rahman, et al., 2016).

Ditinjau dari karakteristik waktu berdasarkan perhitungan bulan. Selama tahun 2018 kasus terjadi secara fluktuatif. Kasus difteri paling tinggi terjadi pada awal tahun yaitu bulan Januari dan paling rendah pada bulan Juni. Tingginya angka kasus difteri pada awal tahun 2018 karena dampak dari tingginya angka kasus difteri di tahun sebelumnya. Di tahun 2017 terjadi 460 kasus dengan angka kematian sebanyak 16 orang. Tingginya angka kasus difteri beriringan dengan belum dilakukannya program Outbreak Response Immunization (ORI) menjadikan bulan Januari merupakan puncaknya kasus difteri terjadi di tahun 2018. Program ORI dilaksanakan 3 putaran pada tahun 2018, yaitu bulan Januari, bulan Juli, dan bulan November. Penurunan kasus difteri terjadi pada bulan Juni, hal tersebut dianggap karena sebagian besar masyarakat telah melakukan imunisasi ulang (booster) sebagai bentuk upaya pertahanan terhadap wabah KLB yang terjadi pada tahun tersebut. Rendahnya angka kasus difteri 
tersebut juga mendukung bahwa program ORI pemerintah berjalan sukses dan menjadi salah satu upaya untuk mencegah terinfeksi penyakit difteri.

\section{Status Imunisasi Penderita Difteri Di Provinsi Jawa Timur}

Menurut Undang-Undang Nomor 36 Tahun 2009 tentang Kesehatan, pemberian imunisasi merupakan cara untuk mencegah penyaki menular serta dapat menekan dan menurunkan angka kematian pada anak. Difteri adalah salah satu penyakit menular dan imunisasi merupakan upaya yang sangat penting dalam mencegah dan mengendalikan penyakit tersebut. Imunisasi merupakan cara untuk menimbulkan dan meningkatkan sistem imun tubuh seseorang secara aktif terhadap suatu penyakit. Pemberian imunisasi DPT ketika usia bayi dan imunisasi DT pada anak usia sekolah merupakan upaya yang dapat dilakukan untuk mencegah penyakit difteri (Dinkes Jatim, 2016). Kelompok usia $\geq 19$ tahun seharusnya telah mendapatkan imunisasi secara lengkap yaitu 7 dosis, namun mayoritas penderita difteri yang didominasi oleh kelompok umur $\geq 19$ tahun tidak imunisasi dan tidak mendapatkan imunisasi secara lengkap (Tabel 3). Pemberian imunisasi booster baru mulai dilaksanakan tahun 2016 sehingga tak banyak masyarakat mengetahui pentingnya pemberian imunisasi tersebut. Hasil penelitian sejalan dengan penelitian sebelumnya dimana dosis pemberian DPT yaitu dosis satu kali, dua kali, tiga kali, dan dosis ulangan dapat mempengaruhi efektivitas vaksinasi sehingga semakin lengkap pemberian DPT maka semakin efektif seseorang akan terlindungi dari infeksi difteri (Nurhandayani, 2013). Pemberian vaksin sebanyak 2 kali sampai 3 kali akan berhasil meningkatkan imunitas lebih besar dibandingkan dengan pemberian vaksin yang hanya dilakukan dengan frekuensi 1 kali (Lubov, 2011).

Berdasarkan pemberian status imunisasi difteri, penderita individu paling banyak sama sekali tidak melakukan imunisasi $(39,45 \%)$, melakukan imunisasi dasar difteri pada usia bayi (30,61\%), dan melakukan imunisasi ulang/booster (29,95\%). Tingginya jumlah penderita difteri yang tidak melakukan imunisasi menunjukkan semakin mudahnya seseorang terinfeksi difteri. Kelompok usia yang paling banyak tidak imunisasi yaitu usia $\geq 19$ tahun. Kekebalan tubuh akan semakin menurun seiring dengan bertambahnya usia. Hal ini sejalan dengan penelitian sebelumnya dimana anak yang tidak imunisasi difteri berisiko terkena difteri lebih mudah dan memiliki daya imunitas yang rendah daripada anak yang diimunisasi difteri (Arifin dan Prasasti, 2017). Seseorang yang memiliki status imunisasi tidak lengkap akan berisiko 5 kali terinfeksi difteri daripada seseorang yang memiliki status imunisasi lengkap. Penelitian lain menunjukkan bahwa status imunisasi berhubungan dengan kejadian difteri di Blitar tahun 2015 (Saifudin et al., 2017). Pemberian imunisasi DPT-HB-Hib bertujuan untuk memberikan kekebalan selama 1-3 tahun (94100\%). Pemberian imunisasi ulang (booster) dosis keempat juga akan menambah kekebalan selama usia 5 sampai 7 tahun, sementara pemberian imunisasi ulang $\mathrm{Td}$ akan meningkatkan titer antibodi protektif terhadap difteri dan tetanus serta dapat diberikan pada usia 10-18 tahun secara aman (Fadlyana et al., 2013). Kekebalan terhadap penyakit difteri terjadi karena pengaruh adanya antitoksin dalam darah dan kemampuan seseorang untuk membuat antitoksin secara cepat. Kemampuan tersebut merupakan akibat dari pemberian imunisasi aktif dari riwayat pernah menderita atau vaksinasi. Kekebalan dalam tubuh tersebut akan menjaga seseorang tidak mudah jatuh sakit, hal ini karena adanya hubungan erat antara penyakit infeksi dengan fungsi kekebalan tubuh (Kaunang et al., 2016). Anak yang tidak mendapatkan imunisasi secara lengkap menjadi sangat rentan dan dapat mengalami kecacatan bahkan kematian.

Ketidaklengkapan imunisasi dapat disebabkan oleh banyak hal seperti anak yang mengalami sakit saat pelaksanaan imunisasi, kurangnya informasi, serta ketidakhadiran petugas. Hal tersebut disampaikan dalam penelitian sebelumnya dimana sebagian ibu memberikan penjelasan tidak melakukan imunisasi secara lengkap yaitu tidak adanya informasi dari bidan (Isnayni, 2016). Alasan tersebut menjadikan perlunya kegiatan follow up terhadap kondisi anak yang sakit agar tetap dapat dilakukan imunisasi, serta kemampuan petugas kesehatan dalam melakukan promosi kesehatan mengenai imunisasi melalui berbagai media seperti brosur, spanduk, maupun pamflet. Ketidaklengkapan pemberian imunisasi juga dapat terjadi karena anggapan imunisasi DPT- 
HB-Hib yang diberikan pada masa usia bayi sudah cukup sehingga tidak perlu dilakukan imunisasi difteri ulang (booster). Hal ini juga didukung dengan penelitian lain yang menyebutkan dimana ketidakpedulian ibu terhadap imunisasi menjadi alasan tidak lengkapnya status imunisasi (Scobie, 2015). Peningkatan pemahaman dan kesadaran dirasa menjadi solusi yang tepat dan dapat disampaikan oleh petugas kesehatan melalui sosialisasi baik dilakukan ketika posyandu maupun kegiatan masyarakat lainnya.

Tabel 2. Gambaran Status Imunisasi Penderita Difteri di Provinsi Jawa Timur Tahun 2018

\begin{tabular}{lrrrrrr}
\hline \multirow{2}{*}{ Status Imunisasi } & \multicolumn{7}{c}{ Usia Penderita Difteri } \\
\cline { 2 - 7 } & $\begin{array}{c}1-2 \\
\text { Tahun }\end{array}$ & $\begin{array}{c}3-5 \\
\text { Tahun }\end{array}$ & $\begin{array}{c}6-11 \\
\text { Tahun }\end{array}$ & $\begin{array}{c}12-18 \\
\text { Tahun }\end{array}$ & $\begin{array}{c}\geq 19 \\
\text { Tahun }\end{array}$ & Total \\
\hline Tidak Imunisasi & 15 & 29 & 36 & 42 & 177 & 299 \\
DPT-HB-Hib 1 (dosis 1) & 1 & 1 & 12 & 16 & 10 & 40 \\
DPT-HB-Hib 2 (dosis 2) & 1 & 3 & 3 & 4 & 2 & 13 \\
DPT-HB-Hib 3 (dosis 3) & 21 & 41 & 50 & 25 & 42 & 179 \\
DPT-HB-Hib booster (dosis 4) & 8 & 38 & 52 & 18 & 13 & 129 \\
DT (1 SD) (dosis 5) & 6 & 15 & 26 & 6 & 1 & 54 \\
Td (2 SD) (dosis 6) & 1 & 6 & 18 & 3 & 2 & 30 \\
Td (5 SD) (dosis 7) & 0 & 1 & 5 & 4 & 4 & 14 \\
\hline
\end{tabular}

Tabel 3. Gambaran Kelengkapan Status Imunisasi Penderita Difteri di Provinsi Jawa Timur Tahun 2018

\begin{tabular}{|c|c|c|c|c|c|c|}
\hline \multirow{3}{*}{ Kelompok Usia } & \multicolumn{4}{|c|}{ Status Imunisasi } & \multirow{2}{*}{\multicolumn{2}{|c|}{ Total }} \\
\hline & \multicolumn{2}{|c|}{ Lengkap } & \multicolumn{2}{|c|}{ Tidak Lengkap } & & \\
\hline & $\mathrm{n}$ & $\%$ & $\mathrm{n}$ & $\%$ & $\mathrm{n}$ & $\%$ \\
\hline 1-2 Tahun & 0 & 0,00 & 53 & 6,99 & 53 & 6,99 \\
\hline 3-5 Tahun & 1 & 0,13 & 133 & 17,55 & 134 & 17,68 \\
\hline 6-11 Tahun & 5 & 0,66 & 197 & 25,99 & 202 & 26,65 \\
\hline 12-18 Tahun & 4 & 0,53 & 114 & 15,04 & 118 & 15,57 \\
\hline$\geq 19$ Tahun & 4 & 0,53 & 247 & 32,59 & 251 & 33,11 \\
\hline
\end{tabular}

\section{KESIMPULAN DAN SARAN}

Distribusi penyakit difteri mengalami peningkatan sejak tahun 2016 hingga tahun 2018 yang terjadi di Provinsi Jawa Timur. Karakteristik penderita difteri di Provinsi Jawa Timur tahun 2018 berdasarkan penggolongan orang berpaling banyak usia $\geq 19$ Tahun $(33,11 \%)$ dan berjenis kelamin laki-laki $(50,6 \%)$. Berdasarkan penggolongan tempat paling tinggi terjadi di Kota Surabaya dan didasarkan waktu kasus difteri tertinggi terjadi pada bulan Januari dan terendah pada bulan Juni. Status imunisasi difteri sangat berperan penting dalam kejadian difteri. Penderita difteri di Provinsi Jawa Timur didominasi dengan status imunisasi yang tidak lengkap $(98,15 \%)$ dan hanya sedikit yang melakukan imunisasi secara lengkap dengan memenuhi 7 dosis imunisasi difteri $(1,85 \%)$. Berdasarkan pemberian status imunisasi difteri, penderita individu paling banyak sama sekali tidak melakukan imunisasi $(39,45 \%)$, melakukan imunisasi dasar difteri pada usia bayi $(30,61 \%)$, dan melakukan imunisasi ulang/booster $(29,95 \%)$. Status imunisasi difteri yang lengkap bertujuan untuk menimbulkan dan menambah sistem imun tubuh agar terhindar dari penyakit infeksi difteri secara maksimal.

\section{DAFTAR RUJUKAN}

1] Arifin, I. F., \& Prasasti, C. I. (2017) Faktor yang berhubungan dengan kasus difteri anak di Puskesmas Bangkalan tahun 2016. Jurnal Berkala Epidemiologi, 5(1), 26-36.

2] Alfiansyah, G. (2017) Penyelidikan epidemiologi kejadian luar biasa (KLB) difteri di Kabupaten Blitar tahun 2015. Preventia, 2(1).

3] Aswad, I.H.Al. dan Shubair, M.E. (2009) Efficacy of diphtheria and tetanus vaccination in Gaza, Palestine. Eastern Mediterranean Health Journal, Vol. 15, No. 2, 2009, p. 285-294.

4] Clarke, K. (2017) Review of the epidemiology of diphtheria 2000-2016. Geneva: World Health Organization.

5] Dinkes Provinsi Jawa Timur. (2011). Pedoman penanggulangan KLB diphteri di Jawa Timur. Surabaya: Dinkes Provinsi Jatim. 
6] Dinkes Provinsi Jawa Timur. (2013) Penyakit difteri per kab./kota di Jawa Timur per tanggal 11 Januari 2013. Surabaya: Dinkes Provinsi Jatim.

7] Dinkes Provinsi Jawa Timur. (2016) Profil kesehatan Provinsi Jawa Timur tahun 2016. Dinas Kesehatan Provinsi Jawa Timur. Surabaya

8] Dinkes Kota Surabaya. (2018) Laporan surveilans difteri di Kota Surabaya tahun 2015-2017. Seksi Surveilans dan Imunisasi Dinas Kesehatan Kota Surabaya. Surabaya.

9] Fadlyana, E., Rusmil, K., Garna, H., Sumarman, I., Adi, S. S., \& Bachtiar, N. S. (2013) Imunogenisitas dan keamanan vaksin tetanus difteri (Td) pada remaja sebagai salah satu upaya mencegah reemerging disease di Indonesia. Sari Pediatri, 15(3), 141-149.

10] Hidayati, R. (2017) Faktor-faktor yang mempengaruhi angka kejadian penyakit difteri di Kota Padang. UNES Journal of Social and Economics Research (JSER), 2(2), 180-187.

11] IDAI, (2011) Pedoman imunisasi nasional di indonesia edisi keempat tahun 2011. Jakarta: IDAI.

12] Isnayni, E. (2016) Hubungan pengetahuan ibu, pendapatan keluarga dan peran keluarga dengan status imunisasi dasar. Jurnal Berkala Epidemiologi, 4(3), 360370.

13] Izza, N., \& Soenarnatalina. (2015) Analisis data spasial penyakit difteri di Provinsi Jawa Timur tahun 2010 dan 2011. Buletin Penelitian Sistem Kesehatan, 18(2), 211219.

14] Kaunang, M. C., Rompas, S., \& Bataha, Y. (2016) Hubungan pemberian imunisasi dasar dengan tumbuh kembang pada bayi (0-1 Tahun) di Puskesmas Kembes Kecamatan Tombulu Kabupaten Minahasa. Jurnal Keperawatan (E-Kp), 4(1), 1-8.

15] Kemenkes RI. (2017) Profil kesehatan Indonesia tahun 2016. Kementerian Kesehatan RI. Jakarta.

16] Lubov, S. (2011) Epidemic diptheria in India 1991-1998. The journal of Infectious Diseases 2001 : p 589:591
17] Mukarami H., Phuong N.M., Thang H.V., Chau N.V., Giao P.N., dan Tho N.D. (2010) Epidemic diphtheria in Ho Chi Minh City Vietnam: a match case-control study to identify risk factors of incidence. Elvesier Vaccine28 (2010), p. 8141-8146.

18] Nurhandayani, Wijaya, H., Lubis, I. N. D., Pasaribu, A. P., Pasaribu, S., \& Lubis, C. P. (2013). Perbandingan efektifitas pemberian imunisasi difteria satu kali, dua kali, dan tiga kali dengan penilaian titer antibodi pada anak. Majalah Kedokteran Nusantara, 46(3), `52-157.

19] Rahman, F. S., Hargono, A., \& Susilastuti, F. (2016) Penyelidikan epidemiologi KLB difteri di Kecamatan Geneng dan Karang Jati Kabupaten Ngawi tahun 2015. Jurnal Wiyata, 3(2), 199-213.

20] Rahmawati, A. I., \& Wahyuni, C. U. (2014) Faktor yang mempengaruhi kelengkapan imunisasi dasar di Kelurahan Krembangan Utara. Jurnal Berkala Epidemiologi, 2(1), 59-70. https://doi.org/10.20473/jbe.V2I12014.5970

21] Saifudin, N., Wahyuni, C. U., \& Martini, S. (2017) Faktor risiko kejadian difteri di Kabupaten Blitar tahun 2015. Jurnal Wiyata Penelitian Sains dan Kesehatan, 3(1), 61-66.

22] Sari, M.F. (2012) Indikator prediktif kejadian difteri di Kota Surabaya. Thesis. .Fakultas Kesehatan Masyarakat Universitas Airlangga, Program Studi Administrasi dan Kebijakan Kesehatan.

23] Scobie, H. M., Ray, A., Routray, S., Bose, A., Bahl, S., Sosler, S., Anand, A. (2015) Cluster survey evaluation of a measles vaccination campaign in Jharkhand, India, 2012. Public Library of Science Journal, 10(5), 1-15.

24] Swart, E. M., Van Gageldonk, P. G. M., De Melker, H. E., Van Der Klis, F. R., Berbers, G. A. M., \& Mollema, L. (2016) Long-term protection against diphtheria in the Netherlands after 50 years of vaccination: results from a seroepidemiological study. PLoS ONE, 11(2), 1-15. https://doi.org/10.1371/journal.pone.01486 05 . 